Abditani : Jurnal Pengabdian Masyarakat 2 (2) 93-99

\title{
PKM KELOMPOK BUDIDAYA LEBAH MADU DESA NAMO KECAMATAN KULAWI KABUPATEN SIGI
}

\author{
Muthmainnah $^{1}{ }^{*}$, Abdul Hapid ${ }^{1}$, Hamka $^{1}$ dan Zulkaidhah ${ }^{1}$ \\ ${ }^{1}$ Fakultas Kehutanan Universitas Tadulako, Palu Sulawesi Tengah \\ Email: wawa.untad@gmail.com
}

\begin{abstract}
ABSTRAK
Pelestarian kawasan hutan dan alam harus dilakukan secara multi efek, artinya pemberdayaan masyarakat dilakukan dengan pendekatan dalam menunjang nilai tambah ekonomi tanpa harus merusak hutan.Salah satu kegiatan yang dilakukan oleh pemerintah adalah budidaya lebah madu bagi masyarakat di sekitar hutan. Kegiatan budidaya lebah madu apabila tidak dikelola secara professional tidak akan memberikan keuntungan bagi masyarakat. Salah satu wilayah di Indonesia khususnya Sulawesi Tengah yang sangat potensial untuk kegiatan budidaya lebah madu adalah Desa Namo, Kecamatan Kulawi, Kabupaten Sigi. Untuk mengatasi permasalahan yang dihadapi masyarakat yang ada di Desa Namo, khususnya kelompok tani budidaya lebah madu maka Tim Pengabdi melakukan pertemuan dengan anggota kelopok tani hutan untuk mengetahui permasalahan-permasalahan yang dihadapi selama melakukan kegiatan budidaya lebah madu. Berdasarkan uraian diatas maka tujuan yang akan dicapai pada program pengabdian ini adalah memberikan pengetahuan bagi mitra tentang teknik budidaya lebah madu yang professional sehingga dapat meningkatkan pendapatan mitra, sehingga dapat mengurangi aktivitas masyarakat di dalam Kawasan Kegiatan yang akan dilaksanakan dalam program pengabdian ini adalah melakukan penyuluhan kepada anggota mitra tentang teori yang berkaitan dengan budidaya lebah, khususnya tentang biologi lebah, peralatan budidaya lebah, analisa usaha perlebahan, hama dan penyakit lebah madu serta tanaman pakan lebah. Juga dilakukan kegiatan pelatihan tentang model cara membuat kotak lebah yang baik duntuk lebah Apis cerana F. Selain itu untuk memberikan pelatihan cara pemindahan koloni lebah dari alam ke kotak lebah. Hasil pengabdian menunjukkan bahwa jenis kayu yang baik untuk digunakan sebagai bahan baku pembuatan kotak lebah adalah kayu kelapa dan kayu bayur. Pada umumnya kelompok tani lebah Mitra telah paham budidaya lebah secara moderen.Budidaya lebah yang dilakukan setelah kegiatan pengabdian memberikan pengaruh peningkatan pendapatan kelompok tani mitra.
\end{abstract}

Kata Kunci: Hutan; Hasil Hutan; Lebah Madu; Pendapatan

\section{Pendahuluan}

Pembangunan di bidang kehutanan hendaknya tidak diartikan hanya untuk meningkatkan menjaga kelestarian hutan saja, akan tetapi harus meliputi semua kegiatan usaha dalam meningkatkan kesejahteraan, derajat dan martabat kaum masyarakat Indonesia khususya masyarakat yang ada di dalam dan sekitar hutan (Marzali, 2016). Salah satu kegiatan usaha yang juga diperlukan mendapatkan perhatian dalam hal ini adalah budidaya lebah madu. Pertimbangan untuk budidaya lebah madu ini selain menguntungkan dan, juga memberikan dampak positif dalam hal penyerapan tenaga kerja (Anggraini et al.). Karena mekanisme dari usaha ternak lebah madu mengharuskan melakukan kegiatan penggembalaan dari satu daerah ke daerah lain, untuk mencari madu dan tepung sari, pada musim bunga tertentu. Kegiatan ini sudah pasti memerlukan tenaga kerja (buruh) yang tidak sedikit. Dari segi kesehatan, madu dipercaya memberikan banyak manfaat untuk pengobatan dan pemeliharaan kesehatan (Sakri, 2012).

Kerusakan hutan dapat menimbulkan berbagai masalah lingkungan antara lain, hilangnya keanekaragaman hewan dan tumbuhan, kekeringan, tanah longsor, banjir, dan yang paling parah lagi adalah meningkatnya suhu bumi atau dikenal dengan global warming (Kehutanan and Betiri, 2011). Untuk mengatasi hal tersebut perlu adanya suatu cara yang harus dilakukan 
pemerintah dan masyarakat untuk menjaga kelestarian hutan salah satunya adalah dengan cara melakukan pemberdayaan masyarakat yang ada di dalam maupun di sekitar hutan melalui kegiatan budidaya lebah madu yang sekaligus bersifat konservatif (Suprayitno, 2008). Selain menjaga kelestarian hutan, budidaya lebah madu juga bisa dijadikan sebagai sarana untuk meningkatkan pendapatan masyarakat khususnya yang tinggal di dalam dan di sekitar hutan, sehingga masyarakat sekitar hutan tidak perlu lagi melakukan kegiatan illegal logging, tetapi beralih melakukan budidaya lebah madu (Setiawan et al., 2016). Program ini diharapkan menjadi simbiosis mutualisme antara masyarakat dengan lingkungan hutannya karena sumber makanan pokok terbesar dari lebah madu adalah nektar bunga yang berasal dari hutan, sehingga ketergantungan untuk ikut menjaga dan melestarikan hutan semakin besar. Usaha pembudidayaan lebah juga akan mendorong masyarakat untuk melakukan kegiatan penanaman di lahan kosong, kebun atau lahan-lahan kering sehingga mengalihkan perhatian masyarakat untuk menebang pohon dalam kawasan hutan. Dengan demikian diharapkan budaya masyaraakat yang semula cenderung melakukan aktivitas dalam hutan beralih ke luar kawasan hutan (Manullang, 1999).

Indonesia sangat cocok untuk usaha budidaya lebah madu, karena sangat banyak (kaya) akan ragam tanaman berbunga dan hasil pertanian dapat diusahakan sepanjang tahun. Ketika musim tanaman berbunga tiba, maka produksi madu akan sangat berlimpah. Dengan jumlah penduduk terbesar keempat di dunia, Indonesia merupakan pasar yang sangat baik. Selain itu di Indonesia terdapat areal daratan sekitar 193 juta hektar dan luas hutan143 juta hektare, merupakan lahan yang sangat luas untuk tanaman berbunga penghasil madu dan tepung sari. Untuk konsumsi madu per kapita di Indonesia masih sangat rendah yaitu sebesar $0,3 \mathrm{~kg}$ per tahun, sedangkan negara Jerman dan Jepang sudah mencapai $1,3 \mathrm{~kg}$ per tahun menurut Pusbahnas (pusat perlebahan nasional).
Melihat kenyataan ini peluang usaha ternak lebah madu sangat baik sekali (Murtidjo, 1991).

Dari produksi nasional madu yang saat ini diperkirakan 8.800 ton, masih jauh dari kebutuhan yang semestinya sekitar 25.000 ton per tahun. Karena itu, Indonesia belum dapat mengeksport madu untuk menghasilkan devisa, karena untuk kebutuhan dalam negeri saja belum terpenuhi(Novandra and Widnyana, 2013). Besarnya kebutuhan madu dalam negeri disebabkan produk yang dihasilkan oleh lebah tidak hanya dipergunakan untuk konsumsi perorangan, tapi juga dibutuhkan oleh industri rokok, makanan, minuman, obat-obatan, susu, roti, sabun mandi, shampo dan sebagainya. Dapat dikatakan bahwa hampir seluruh wilayah hutan di Indonesia terdapat lebah hutan apis dorsata yang sangat produktif menghasilkan madu. Untuk lebah lokal apis cerana yang produktif menghasilkan madu juga tersebar di seluruh kepulauan nusantara. Demikian juga dengan lebah impor apis mellifera Linnaeus juga telah berhasil dikembangan dan dapat beradaptasi dengan baik di alam lingkungan Indonesia (Hamzah, 2011).

Salah satu wilayah di Indonesia khususnya Sulawesi Tengah yang sangat potensial untuk kegiatan budidaya lebah madu adalah Desa Namo, Kecamatan Kulawi, Kabupaten Sigi. Desa Namo telah telah berhasil memperoleh pengakuan pengelolaan hutan desa, berdasarkan keputusan Menhut nomor 64/2011, desa ini mengelola wilayah Hutan Desa seluas 490 hektar, yang merupakan bagian dari sistem daerah aliran sungai (DAS) Palu, sub DAS Miu. Dari 490 hektar, 400 hektar dialokasikan sebagai zona lindung dan sisanya 90 hektar diperuntukkan untuk fungsi pemanfaatan. Wilayah hutan Desa Namo merupakan sumber pakan lebah madu yang potensial dan termasuk wilayah yang memiliki udara sub tropis, sangat ideal untuk mengembang biakkan dan membudidayakan lebah, karena rata-rata suhu udaranya 26 $35^{\circ} \mathrm{C}$ (Tjatjo, 2015). 
Abditani : Jurnal Pengabdian Masyarakat 2 (2) 93-99

e-ISSN : 2622-4690

p-ISSN : 2622-4682

Keberadaan kelompok tani yang melakukan budidaya lebah di Desa Namo Kecamatan Kulawi Kabupaten Sigi ini juga menjadi lokasi bagi Mahasiswa Fakultas Kehutanan Universitas Tadulako untuk kegiatan praktek lapang dan lokasi untuk melakukan penelitian tugas akhir. Berdasarkan laporan hasil praktek mahasiswa dan skripsi tugas akhir yang ada selama ini menunjukkan bahwa masih sangat banyak kekurangan-kekurangan yang ditemui di lokasi sehubungan dengan kegiatan budidaya lebah. Hal ini disebabkan oleh pengetahuan para peternak lebah yang masih sangat terbatas.

Untuk mengatasi permasalahan yang dihadapi masyarakat yang ada di Desa Namo, khususnya kelompok tani budidaya lebah madu maka Tim Pengabdi melakukan pertemuan dengan Tokoh Masyarakat, Kepala Desa dan anggota kelopok tani hutan untuk mengetahui permasalahanpermasalahan yang dihadapi selama melakukan kegiatan budidaya lebah madu. Melalui pertemuan tersebut, permasalahan yang disepakati untuk diselesaikan melalui program pengabdian adalah:

1. Kurangnya pengetahuan masyarakat tentang tata cara budidaya lebah

2. Desain kotak lebah masih sangat sederhana sehingga kurang mendukung perkembangan lebah, dan masih ada beberapa lebah yang dipelihara di bekas kandang ayam.

3. Anggota kelompok tani budidaya lebah madu masih sangat lemah dalam hal permodalan sehingga belum mampu mengakses teknologi tepat guna untuk meningkatkan produktivitas dan kualitas madu.

4. Peralatan pendukung untuk kegiatan budidaya lebah madu masih sangat kurang sehingga kegiatan seperti pemanenan dilakukan secara tradisional yang menyebabkan rendamen madu masih kurang.

5. Kualitas madu yang dihasilkan masih rendah seperti masih ada ampas sarang.

6. Masih terbatasnya jumlah koloni sehingga hasil madu juga masih kurang.
7. Kemasan madu yang dijual petani juga tidak menarik sehingga berpengaruh terhadap harga madunya.

\section{Metode Pelaksanaan}

\section{Waktu dan Tempat Pengabdian}

Kegiatan pengabdian dilakukan mulai bulan Maret sampai bulan September 2019 diDesa Namo, Kecamatan Kulawi, Kabupaten Sigi.

\section{Metode Pendekatan}

Kegiatan ini pada dasarnya merupakan kegiatan dalam bentuk pendidikan kepada masyarakat. Metode pendekatan yang dipilih adalah penyuluhan, pelatihan yang dilanjutkan dengan penerapan teknologi dan pendampingan. Metode yang digunakan adalah persuasif-edukatif-komunikatifpartisipatif. Dalam melaksanakan metode tersebut prinsip-prinsip andragogy (pendidikan orang dewasa) dijadikan sebagai pedoman. Untuk itu akan dikembangkan prinsip nilai manfaat yang sesuai dengan pengalaman, praktis, menarik, partisipasi aktif, dan kemitraan. Untuk itu akan dilakukan tiga (3) langkah-langkah solusi atas persoalan yang disepakati bersama berupa kegiatan:

\section{a. Penyuluhan/Penyadaran Penyuluhan Konsep Beternak Lebah Madu}

Penyuluhan didefinisikan sebagai sistem pendidikan luar sekolah di bidang pertanian untuk petani, nelayan dan keluarganya serta anggota masyarakat pertanian agar dinamika dan kemampuannya dalam memperbaiki kehidupan dan penghidupan dengan kekuatan sendiri dapat berkembang, sehingga dapat meningkatkan peranan dan peran sertanya dalam pembangunan pertanian (Sadono, 2008). Kegiatan ini meliputi: Penyuluhan konsep beternak lebah madu akan diberikan yang berasal dari Tim Pengabdi dari Fakultas Kehutanan Universitas Tadulako, sedangkan peserta adalah anggota kelompok tani lebah diDesa Namo. Dalam penyuluhan ini akan diberikan ceramahuntuk menjelaskan prinsipbeternak lebah yaitu prinsip memilih 
kayu untuk dibuat kotak lebah, memilih bibit koloni lebah yangbaik untuk dikembangkan, juga dijelaskan keuntungan secara ekonomispada pembudidayaan lebah tersebut.Ceramah diberikan juga disertai tanya jawab antara peserta dengan penyuluh dari Fakultas Kehutanan. Peternak akan diberi materi yang sederhana dan aplikasi sehingga dapat dengan mudah mereka pahami dan aplikasikan pada ternak lebahnya.

\section{b. Pelatihan}

Kegiatan pelatihan menggunakan metode ceramah, diskusi dan tutorial. Metode ceramah digunakan untuk memberikan pemahaman yang lengkap kepada para peserta tentang cara pemilihan lokasi budidaya lebah madu, cara pembuatan kotak lebah yang baik, cara pengedalian hama dan penyakit, cara pemanenan lebah secara modern dan manajemen pemasarannya (Mutmainnah et al., 2018). Dalam ceramah diuraikan kerangka materi secara lengkap, jelas, mudah dipahami, dan aplikatif. Metode ceramah dalam pelatihan ini diusahakan untuk menghindari pembahasan teoritis yang barlarut-larut dan lebih menekankan pada contoh-contoh kasus yang dialami sendiri oleh pekebun beserta cara pemecahannya (Hapid et al., 2018). Penyajian materi dilanjutkan dengan tanya-jawab dan diskusi.

Kegiatan pelatihan ini dilakukan dengan cara penerapan langsung di lapangan tentang desain kotak lebah, pengadaan peralatan serta penambahan koloni lebah.

\section{Pelaksanaan pelatihan}

- Cara pembuatan Kotak lebah:

Pengetahuan dasar yang harus dibekali petani lebah madu dalam pembuatan kotak lebah/stup adalah sifat-sifat kayu khususnya sifat kimia kayu (zat ekstraktif). Berdasarkan hasil penelitian (12) menunjukkan kayu yang mengandung zat ekstraktif berbau dan beraroma khas dan tidak disukai lebah akan menyebabkan suasana di dalam kotak tidak disukai lebah sehingga lebah tidak beraktivitas di dalam kotak.

\section{c. Pendampingan}

Untuk lebih meningkatkan keterampilan kelompok petani budidaya lebah madu dalam hal pembuatan kotak lebah, proses pemanenan lmadu dan pemasarannya, maka dilakukan kegiatan pendampingan. Selain itu juga dilakukan evaluasi secara periodik untuk keterampilan penguasaan teknologi pemanenan madu dan pola manajemen usaha pertanian sehingga kegiatan ini dapat berkelanjutan dan pada akhirnya terbentuk masyarakat yang mampu melakukan usaha mandiri yang berbasis produk hasil hutan bukan kayu khususnya madu dan produk lainnya seperti propolis.

\section{Evaluasi Pelaksanaan Program dan Keberlanjutan Program Setelah Dilaksanakan}

Keberhasilan pelaksanaan program ini dapat diukur dari sejauh mana respon mayarakat terhadap program tersebut, kualitas dan kuantitas produk yang yang dihasilkan, serta peningkatan hasil lebah madu dan kualitas madu yang dihasilkan yang berdampak pada peningkatan pendapatan kelompok tani mitra.

Keberlanjutan program ini setelah pengabdian dilaksanakan diharapkan kelompok tani mandiri sehingga terbentuk masyarakat yang mampu melakukan usaha mandiri yang berbasis lebah madu serta mengetahui manajemen usaha hasil hutan bukan kayu.

\section{Hasil dan Pembahasan}

\section{a. Penyuluhan Budidaya Lebah Madu}

Proses pengenalan budidaya ini dijelaskan kepada peserta olehTim pengabdi dari Fakultas Kehutanan Univeritas Tadulako. Produk akhir yang akan dihasilkan melalui proses pembudidayaan lebah adalah lebahmadualamiyang dihasilkanolehlebah lokal jenis Apis cerana melalui proses pembudidayaan (diternakkan). Madu alami yang dihasilkan,bersumber dari nektar yang dihisap oleh lebah dari bunga tanaman.Saat mencari nektar, lebah juga sebenarnya sedang membantu proses penyerbukan 
bunga tanaman, dimana hal iniadalah proses penting dalam perkembangbiakan tanaman.Rasa madu yang manis diperoleh dari proses biologis yang menghasilkan monosakarida, fruktosa dan glukosa pada madu.

Nektar yang diperoleh lebah pekerja dari bunga tanaman,akan dibawa kembali ke sarangnya.Setelah nektar dikumpulkan, lebah kembali ke sarangnya dan selanjutnya lebah pekerja lain (biasanya lebih muda) mengisap nektar dari perut lebah pekerja yang baru pulang menggunakan proboscis. Lebah pekerja muda yang berada disarang lantas mengubah nektar menjadi madu.Hal ini dilakukan dengan menambahkan berbagai enzim dari mulut lebah pekerja ke nektar untuk kemudian mengubahnya menjadi madu mentah. Proses ini memakan waktu sekitar 20 menit. Madu mentah yang dihasilkan selanjutnya disimpan di dalamsarang tempat madu. Pada tahap inimadu masih memiliki kandunganairtinggi. Madu mentahselanjutnya akan secara berangsur berkurang kadar airnya. Kepakan sayap lebah dalam sarang merupakan salah satu cara lebah untuk menurunkan kadar air dalam madu mentah. Madu dianggap matang jika kadar air telah turun kelevel tertentu. Madu yang telah matang akan dilindungi dan disimpan dengan bantuan lilin yang dihasilkan oleh semacam lembaran yang ada di bawah perut lebah. Setelahproses ini, madu siap untuk digunakan oleh koloni lebah madu atau dipanen oleh manusia (Sebayang et al., 2017).

\section{b. Pelatihan Pembuatan Kotak Lebah}

Setelah dilakukan kegiatan pengenalan akan budidaya ternak lebah kepada peserta, maka selanjutnya dilakukan pelatihan dan demonstrasipembuatansarang lebahdarikotak buatan.

Saranglebahbuatanberupa kotak kayu, dibuatmenggunakankayu papanyangkokoh agartahanlama dan kayu yang sudah kering dan tidak berbau.Kayu yang digunakan untuk membuat kotak lebah pada saat pelatihan adalah kayu kelapa dan kayu bayur, kayu ini sudah terbukti disukai lebah.
Berdasarkan hasil penelitian menunjukkan kayu yang mengandung zat ekstraktif berbau dan beraroma khas akan menyebabkan suasana di dalam kotak tidak disukai lebah sehingga lebah tidak beraktivitas di dalam kotak (Muhazan, 2015).

1. Dalam pelatihan ini desain kotak yang akan dibuat adalah desain kotak vertikal jepang yang dimodifikasi berupa tambahan lubang ventilasi pada dinding kanan dan kiri kotak lebah dengan ukuran $10 \mathrm{~cm}$ x $0,3 \mathrm{~cm}$. Ukuran kotak lebah yang akan dibuat sebagai berikut:

$\checkmark$ Tutup:4,5 cm x $36 \mathrm{~cm} \times 33 \mathrm{~cm}$

$\checkmark$ Dalam Kotak:30,5 cm x $24 \mathrm{~cm}$ x $18 \mathrm{~cm}$

$\checkmark \quad$ Alas : $28,5 \mathrm{~cm} \times 21 \mathrm{~cm} \times 2,5 \mathrm{~cm}$

$\checkmark \quad$ Pintu masuk:2 cm x 0,5 cm

$\checkmark$ Volume kotal:23,058 $\mathrm{cm}^{3}$

Setelah kotak sudah terpasang secara mantap, maka koloni lebah(yang terdiri dari ribuan lebahpekerja dan lebah ratu dimasukkan ke dalamnya).Setiap koloni terdiri dari satu ratu dan lebih dari delapan ribu pekerja. Pembiakan koloni baru berasal dari teluryang dihasilkan oleh ratu disetiap koloni. Pemanenan madu dapat dilakukan setelah 10-15 hari masa tunggu.

\section{c. Proses pemindahan koloni dari alam ke dalam kotak lebah dan pembudidayaan ternak lebah madu.}

Setelah kotak lebah selesai dibuat, maka selanjutnya kotak tersebut digantung (diikat dan dipaku) di pohon kelapa.Tinggi wadah ini dari permukaan tanah berkisar 1,3meter. Setelahwadah telah tergantung secara mantap diatas pohon, maka koloni lebah yang ada di lubang pohon kelapadipindahkan atau dimasukkan kedalam wadah atau kotak.Dalam proses pemidahan ini, seluruh tubuh dan wajah ditutupi kain kelambu, kaos tangan dan topi sebagai alat pelindungsengatan lebah (Sebayang et al., 2017).

Sarang lebah yang berisi lebah ratu yang pertama sekali dimasukkan kedalam wadah kotak. Lebah lainnya dalam waktu sekitar satujamakan beterbangan tidakjauh disekitar wadah. Lebah-lebah ini selanjutnya akan berkumpul menumpuk disekitar kotak 
dan akhirnya masuk kedalam sarang mendekatidan diam bersama lebah lebah ratu yang telah ada di dalam wadah. Pada lebah-lebah ini akan memproduksi madu yang bersumber dari sari bunga tanaman yang ada disekitar lokasi. Panen dilakukan sekitar 2-3 bulan setelah koloni dipindahkan ke dalamwadah (Sebayang et al., 2017).

\section{d. Pemanenan Madu}

Proses pemanenan madu harus dilaksanakan pada waktu yang tepat agar hasilnya memuaskan. Pemilihan waktu yang tepat ini akan memaksimalkan kuantitas dan kualitas madu yang ada di dalam sarang lebah. Jika salah dalam memilih waktu panen, maka kemungkinan besarnya ialah jumlah madu yang bisa dipanen sangat sedikit atau bahkan kosong (Said, 2017).

Panen madu lebah bisa dimulai jika jumlah lebah dalam satu koloni sarang minimal 20.000 ekor yang memenuhi sisir sarang. Ciri-ciri madu siap dipanen adalah diantaranya sisiran pada sarang telah tertutup rapat oleh lapisan lilin tipis, kemungkinan madu di dalam sarang sudah mencukupi syarat untuk dipanen, Ukuran sarang memendek atau mengecil dari sebelumnya, bagian bawah sarang terlihat menipis dan sekitar sarang terlihat lebih sudah bersihsisirantelahyang ada telah tertutupoleh lapisan lilin tipis. Sisiran yang akan dipanen dibersihkan dulu dari lebah yang masih menempel, kemudian lapisan penutup sisiran dikupas. Setelah itu sisiran diekstraksi untuk diambil madunya.. Proses pemanenan lebah madu dilakukan dengan cara tradisional, dengan cara memanaskan sisiran sarang lebah dengan bantuan air mendidih (Sebayang et al., 2017).

\section{Langkah-langkah pengumpulan madu secara tradisional}

Langkah-langkah pengumpulan madu secara tradisionalyaitu sebagaiberikut:

1. Perlengkapan kerja khusus (kelambu tutup kepala, kaos tangan dan topi) dipakai saat memanen lebah madu.

2. Air panas dimasukkan didalam panci yang berukuran besar, Air panas ini nantinya Digunakan untuk memisahkan madu dari sisiran sarang.

3. Kotak lebah madu dibuka dari sisi samping atau belakang lubang keluar masuk lebah madu.

4. Lakukan pengasapan pada kotak lebah madu. Pengasapan ini dilakukan untuk mengalihkan perhatian kumpulan lebah madu dan untuk mempermudah pemanenan.

5. Sisiran sarang yang dipenuhi oleh lebah madu diambil dengan bantuan alat pengungkit.

6. Selanjutnya sisiran sarang dibersihkan dari kerumunan lebah madu dengan sikat lebah.

7. Letakkan tempat sisiran yang berisi madu tersebut ditempat yang datar.

8. Potong sisiran sarang lebah madu tersebut dengan pisau.Pemotongan itu dilakukan pada batas antara deretan sarang yang berisi madu.

9. Masukkan potongan tersebut kedalam panciyang berukuran lebih kecildaripanci yangdigunakan untuk merebusair.

10. Hasil potongan sisiran sarang yang berisi madu ini siap untuk dipanaskan. Pemanasan ini dilakukan supaya madunya keluar dari sisiran sarang.

11. Setelah air yang ada di panci besar mendidih, masukkan potongan sisiran sarang lebah madu yang berada dipanci kecil ke dalam panci besar untuk dipanaskan.

12. Sistem pemanasan ini akan menyebabkan cairan lengket seperti lilin yang menutupi sela-sela sarang madu akan mencair. Kemudian, secara otomatis madunya akan keluar dari sela-sela sarang tersebut.

13. Setelah madunya semua keluar, angkat panci yang berisi potongan sisiran sarang lebah tadi dari kompor,dan biarkan hingga dingin supaya cairan lilin lebah dan madunya terpisah.

14. Madu yang telah terpisah dari lilin lebah ini segera dimasukkan kedalam botolatau wadah lain, melalui saringan. Hal ini untuk memisahkan madu dari kotoran lainnya. 
Madu yang dihasilkan oleh lebah madu ada yang berkualitas baik dan ada yang tidak. Beberapa faktor yang dapat mempengaruhi produksi madu dalam sarang antara lain ketersediaan nektar dan serbuksari (Muhazan, 2015), ketersediaanselteluryang terbukauntuk peletakan, jumlah lebah perawat,dan vitalitas keseluruhan serta kualitas sang ratu.

\section{Kesimpulan}

Berdasarkan hasil pelaksanaan pengabdian pada Kelompok tani lebah madu namo di Desa Namo, Kecamatan Kulawi, Kabupaten Sigi dapat disimpulan bahwa jenis kayu yang baik untuk digunakan sebagai bahan baku pembuatan kotak lebah adalah kayu kelapa dan kayu bayur. Pada umumnya kelompok tani lebah telah paham budidaya lebah secara moderen. Kotak lebah yang digunakan hasil pelatihan memberikan pengaruh peningkatan pendapatan kelompok tani mitra.

\section{Ucapan Terima Kasih}

Ucapan terima kasih penulis kepada Direktorat Riset dan Pengabdian Masyarakat, Direktorat Jenderal Penguatan Riset dan Pengembangan Kementerian Riset, Teknologi dan Pendidikan Tinggi yang telah membiayai kegiatan pengabdian ini melalui skim PKM tahun anggaran 2019.

\section{Daftar Pustaka}

Anggraini AD, Kassa S and Laapo A Analisis Titik Pulang Pokok USAha Budidaya Lebah Madu "Jaya Makmur" di Desa Jono Oge Kecamatan Sigi Biromaru Kabupaten Sigi.Agrotekbis 4.

Hamzah D (2011) Produksi Lebah Madu (Apis cerana) yang Dipelihara Pada Sarang Tradisional dan Moderen di Desa Kuapan Kecamatan Tambang Kabupaten Kampar, Universitas Islam Negeri Sultan Sarif Kasim Riau.

Hapid A, Wardah W, Massiri SD and Hamka H (2018) Pengembangan Desa Mitra di Desa Bakubakulu Kecamatan Palolo Kabupaten Sigi.Abditani1:35-42.

Kehutanan TBL and Betiri TNM (2011) Review tentang Illegal Logging sebagai Ancaman terhadap Sumber Daya Hutan dan
Implementasi Kegiatan Pengurangan Emisi dari Deforestasi dan Degradasi di Indonesia. Bogor: Puslitbang Kementerian Kehutanan.

Manullang S (1999) Kesepakatan Konservasi Masyarakat dalam Pengelolaan Kawasan Konservasi, Departemen Kehutanan dan Perkebunan.

Marzali A (2016) Antropologi \& Pembangunan Indonesia, Prenada Media.

Muhazan M (2015) Pengaruh Disain Kotak Terhadap Produksi Madu Dan Propolis Lebah Trigona Di Desa Genggelang Kabupaten Lombok Utara, Universitas Mataram.

Murtidjo BA (1991) Memelihara lebah madu, Kanisius.

Mutmainnah M, Hapid A and Hamka H (2018) Pkm Kelompok Tani Aren di Sekitar KPH Tinombo Dampelas Sulawesi Tengah. Abditani 1:58-64.

Novandra A and Widnyana I (2013) Peluang pasar produk perlebahan Indonesia.Balai Penelitian Teknologi Hasil Hutan Bukan Kayu.

Sadono D (2008) Pemberdayaan petani: paradigma baru penyuluhan pertanian di Indonesia. Jurnal penyuluhan4.

Said DO (2017) Sistem Produksi dan Curahan Waktu Pembudidayaan Lebah Madu (Apis cerana) di Kabupaten Lombok Utara. Fakultas Peternakan, Universitas Nahdlatun Wathan Mataram.

Sakri FM (2012) Madu dan Khasiatnya: Suplemen Sehat Tanpa Efek Samping, Diandra Kreatif.

Sebayang T, Salmiah S and Ayu SF (2017) Budidaya Ternak Lebah Di Desa Sumberejo Kecamatan Merbau Kabupaten Deli Serdang.ABDIMAS TALENTA2:168178.

Setiawan A, Sulaeman R and Arlita T (2016) Strategi pengembangan usaha lebah madu kelompok tani setia jaya di desa rambah jaya kecamatan bangun purba kabupaten rokan hulu.Jurnal Online Mahasiswa Fakultas Pertanian Universitas Riau 3:1-9.

Suprayitno AR (2008) Pelibatan Masyarakat Lokal: Upaya Memberdayakan Masyarakat Menuju Hutan. Jurnal Penyuluhan 4.

Tjatjo NT (2015) Karakteristik pola agroforestri masyarakat di sekitar hutan Desa Namo Kecamatan Kulawi Kabupaten Sigi. JSTT 4. 